\title{
Judicial Accountability: The Eternal Dilemma
}

\author{
Udai Singh* and Apoorva Tapas**
}

\begin{abstract}
The deliberation on the lack of transparency and the vociferous demand for a mechanism to ensure accountability in public life has gathered momentum in the recent past. Judicial independence and accountability are the prerequisites for a transparent judiciary enjoying public confidence, which is the hallmark of a healthy democracy. This article seeks to examine the relationship between accountability and independence of the judiciary in view of the need and urgency of transparency, due to various controversies surrounding the Judiciary. The apparent dichotomy between the two is also elaborated. It is premised that judicial independence has an inextricable relationship with judicial accountability. The dichotomy between the two is rather superimposed and the need of the hour is to dispel this very myth.

Viewing accountability to be at loggerheads with independence overlooks their subtle relationship. The former, if unbridled, leads to a crisis of legitimation of the law, posing a challenge for the judiciary to establish its independence. The element of accountability, thus, needs to be secured steadfastly and must be seen as a supplement of independence, and not a hindrance thereto.
\end{abstract}

* Fourth Year, BA LLB, National Academy of Legal Studies and Research University of Law, Hyderabad.

** Fifth Year, BA LLB, New Law College, Bharati Vidyapeeth University, Pune, Maharashtra. 
Keywords: Judicial Accountability, Judicial Independence, Public Interest, Right to Information

\section{Introduction}

"In a pluralist society judges are the essential equalisers. They serve no majority or any minority either. Their duty is to the law and to justice. They do not bend the knee to the governments, to particular religions, to the military, to money, to tabloid media or the screaming mob. In upholding law and justice, judges have a vital function in a pluralist society to make sure that diversity is respected and the rights of all protected."

-Justice Michael Kirby ${ }^{1}$

On numerous occasions, the activist stance and creative interpretation of the judiciary has proved that it plays a vital role in protecting individuals against the misuse of state power while functioning as the custodian of their rights. As the final arbiter and enforcer of the constitutional limitations on government, it has the power to prevent the powerful engines of executive authority from running amok and must therefore be above board in its moral standards in dispensation of justice. Being a cornerstone of democracy, ${ }^{2}$ the presence of a strong, independent and efficient judiciary, both in letter and spirit, is indispensable for guaranteeing constitutional rights.

While many judicial decisions have shaped the Indian polity to a great extent, ensuring fairness in the process of governance, nonetheless, allegations questioning the integrity of this great institution have increased manifold, ascribable to the lack of transparency. Rampant corruption and lack of accountability have

1 Poornima Advani, All India Meeting of Chief Justices of High Courts on Women Empowerment vis-a-vis Legislation and Judicial Decision (Jan. 2005),

http:/ / ncw.nic.in/pdfreports/All \%20India $\% 20$ Meeting $\% 20$ of $\% 20$ chief $\% 2$ 0Justice.pdf.

${ }^{2}$ All India Judge's Association v. Union of India, (2002) 4 S.C.C. 247 \24 (establishing that is part of the basic structure doctrine); see also S.C. Advocates on Record v. Union of India, A.I.R. 1994 S.C. $268 \uparrow 421$. 
diluted the trust reposed in the conscience keepers of the law. Legality is not legitimacy anymore for the Indian people. The 'consensual foundations' of the law are under a great stress. Our legal system suffers from endemic delays and is widely perceived to be an expensive affair. There is a dire need for judicial accountability to arise from within, to ensure a system of operative checks and balances to prevent any unwarranted usurping of power. Unfortunately, this has been met with resistance from within the judiciary, afraid of encroachment into the realm of its independence. This paper debates the ills which are affecting the Indian judiciary. It makes certain recommendations which can be adopted to ensure greater judicial accountability.

\section{Corruption in Judiciary}

In the last few decades, corruption has steadily spread its tentacles in the Indian judiciary. Corruption is encountered in the guise of bribery, influence peddling, intimidation and coercion. ${ }^{3}$ It is driven by many factors including executive interference, lack of citizen voice, social pressure and low salaries. Judicial corruption in addition to corroding the rule of law also undermines the effectiveness of other institutions.

Though the issue of accountability has plagued the judiciary for long, the recent spate of scandals have precipitated a crisis. Never before have such grave charges been levied against the judiciary. 4 Even judges of the High Court and Supreme Court are suspected of bribery and delinquency. Today, the decrepit judiciary suffers from

\footnotetext{
3 UPENDRA BAXI, THE CRISIS OF INDIAN LEGAL SYSTEM (1 ${ }^{\text {st }}$ ed. 1982).

${ }^{4}$ Shoma Chaudhury, Half of the Last 16 Chief Justices were Corrupt, TEHELKA, Sept.5, 2009,

http:/ / www.tehelka.com/story_main42.asp?filename=Ne050909half_of.a sp ("Prashant Bhushan stated that out of the last 16 Chief Justices of India, eight were definitely corrupt"); see also Eight of 16 CJIs were corrupt: Ex-law minister, FRONTLINE, Sept. 16, 2010,

http:/ / www.thestatesman.net/index.php?option=com_content\&view=ar ticle\&id=341694\&catid=36 ("Shanti Bhushan while impleading himself in the Contempt case pending against his son put forth the case affected the judiciary as a whole and needs to be decided by the entire court").
} 
a syndrome of unbecoming behaviour. ${ }^{5}$ The lack of judicial accountability is visibly acute in the higher judiciary, since the lower judiciary is accountable to the High Courts. ${ }^{6}$ Thus, corruption in the higher judiciary is presumably more than that in the lower judiciary, considering the fact High Courts being vested with the power would take serious steps to curb corruption in the lower judiciary.

From a bird's eye-view, it is apparent that two paralegal systems are functioning: one for the rich and resourceful wielding power and influence, another for those who do not to have the capability to fight injustice. The enforcement of rights and liabilities varies with the positioning in the socio-economic structure.

\section{'Absolute Power Corrupts': Impeachment a Farce}

"Men who make their way to the Bench sometimes exhibit vanity, irascibility, narrowness, arrogance and other weaknesses to which human flesh is heir." 7

Corruption is a malaise that is quick to permeate through all strata of society, if unchecked by appropriate regulatory mechanisms. While corruption is reprehensible in any form, judicial corruption is by far the worst form due to the sublime position of the judiciary. Can we yield to it and be indifferent? Can petty corruption of the kind practiced by clerks be equated with corruption in the judiciary? The underlying philosophy of accountability operates in an attempt to bypass this very perverse manifestation of widespread arbitrariness and corruption. The need for accountability, desirable for the efficient functioning of any institution, assumes a greater significance in this context.

At the time of framing the Constitution, it was believed that misconduct by judges of the higher judiciary would be very rare. The Constitution prescribed impeachment as the only way of

${ }^{5}$ V.R. Krishna Iyer, Time for change, FrontLINE, Feb. 26 to Mar. 11, 2011,

http:/ / www.frontlineonnet.com/fl2805/stories/20110311280510600.htm.

6 THE CONSTITUTION OF INDIA, art.227(1).

7 Sacher v. United States, 343 U.S. 1, 12 (1952). 
removing the judges, that too on the basis of proven misbehaviour or incapacity. ${ }^{8}$ These expectations have long been belied by the infamous impeachment of Justice V. Ramaswami. ${ }^{9}$ The realisation of impeachment being virtually impossible due to the long drawn out and impractical process ${ }^{10}$ has instilled a feeling of impunity amongst judges.

The Supreme Court (hereinafter referred to as 'SC') is powerless to take any action against an errant judge and at best can disallow him from hearing cases. The government too, lacks constitutional competence to investigate allegations against the higher judiciary. Till now, there have been only three instances of investigation against the judges of the higher judiciary under the Judges (Inquiry) Act, 1968. ${ }^{11}$

Witness the farce over Justice Dinakaran, former Chief Justice of High Court of Karanataka, who even while facing impeachment proceedings in the Rajya Sabha over grave charges of corruption, was allowed to take over as Chief Justice of the Sikkim High Court. Is it sadly implicit that the people of north-east region merit lower standards of justice?

8 The COnSTITUTION OF INDIA, art.124(4) read with art. 124(2)(b) and art. 217(1)(b).

${ }^{9}$ Dubious First, TEHELKA, Dec. 30, 2006,

http://www.tehelka.com/story_main24.asp?filename=Ne123006Dubious_first.asp (Justice Ramaswami of the Supreme Court was sought to be impeached on grounds of brazen financial irregularities committed by him. Despite the Inquiry Committee holding him "guilty of willful and gross misuses of office", the motion was defeated in Parliament. This was done by unscrupulous politicians involved in the false rivalry between North and South).

${ }^{10}$ K. Veeraswami v. Union of India and Ors., 1991 S.C.C. (3) 655 (the Supreme Court violated the statutory provision of the Criminal Procedure Code, 1973 in its judgment by stating that no First Information Report(FIR) can be registered against any judge without the permission of the Chief Justice of India. This is a classic Catch-22 situation, wherein the police cannot dare to approach the CJI without foolproof evidence, which cannot be obtained without investigation).

11 Justice Soumitra Sen, Justice Dinakaran and Justice Nirmal Yadav. See Chaudhury, supra, note 4. 
It is prima facie evident that there is lack of credible mechanisms for securing accountability of the higher judiciary. It thus becomes imperative that the judges are appointed after investigation into their antecedents and class bias. The need of the hour is to curb delinquency in the judiciary to salvage its grace through the enactment of a legislation. There should be zero tolerance towards tainted judges, exemplary punishment being dispensed as a deterrent.

The Judges (Inquiry) Bill, 2006 was introduced in the Lok Sabha after incorporating almost all of the Law Commission of India's recommendations. It sought to establish a National Judicial Commission ${ }^{12}$ to investigate individual complaints and motions for removal of a judge moved in Parliament. Amongst the many glaring flaws in this Bill was the constitution of the Council consisting of members of the judiciary to investigate and inquire into allegations arising out of complaint or reference. Judicial accountability is generally sought effectively through an external regulatory authority. Ironically, the in-house procedure comprises of sitting judges to investigate into the alleged charges of misconduct, posturing themselves in the garb of an external authority. This negates the very purpose of seeking accountability as it violates the principle of natural justice, that no man shall be the judge in his own cause. ${ }^{13}$

The Judicial Standards and Accountability Bill, $2010^{14}$ seems to be the only hope in the right direction. Optimistically, it will not meet the same fate as its predecessor. 15

${ }^{12}$ Comprising of the Chief Justice of India, two Supreme Court judges and two High Court Chief Justices for investigating High Court judges; or the Chief Justice of India and four Supreme Court judges for investigating Supreme Court judges.

${ }^{13}$ Nemo judex in causa sua.

14 Department Related Parliamentary Standing Committee On Personnel, Public Grievances, Law And Justice Invites Suggestions On The Judicial Standards And Accountability Bill, 2010, http:// 164.100.24.167/ newcommittee/press_release/press/Committee \%20on \%20Personnel, $\% 20$ PublicGrievances,\%20Law\%20and\%20Justice/JSA\%20Bill.pdf (last visited Aug. 23, 2012) (introduced in Lok Sabha on $1^{\text {st }}$ December, 2010 and seeks to 74 


\section{Judicial Independence}

"The principle of the complete independence of the judiciary from the executive is the foundation of many things in our island life. It is perhaps one of the deepest gulfs between us and all forms of totalitarian rule." -Sir Winston Churchill16

An independent judiciary is the bulwark of governance. The provisions of appointment of Judges to the higher judiciary ${ }^{17}$ and the conduct of the Judges, ${ }^{18}$ whereby duties discharged by judges cannot be discussed in the Parliament or State Legislature insulate the judiciary from political processes.

While there has always subsisted a tussle between the legislature and the executive to assume control over the judiciary, 19 an independent judiciary free from unwarranted political interference has been held to be a sine qua non for a democratic society. ${ }^{20}$ 'The Basic Principles on Independence of the Judiciary' ${ }^{21}$ adopted by the United Nations in 1985 and 'The Beijing Principles on the

repeal The Judicial (Inquiry) Act, 1968. Department Related Parliamentary Standing Committee on Personnel, Public Grievances, Law and Justice press release).

15 The Constitution (Ninety-Eighth Amendment) Bill, 2003; see also The Judges (Inquiry) Bill, 2006 and The Judges (Declaration of Assets and Liabilities) Bill, 2009 (which lapsed due to dissolution of the Lok Sabha).

16 PARL. DEB., H.C. (4 $4^{\text {th }}$ ser.) (1954) 1061 (U.K.).

17 THE CONSTITUTION OF INDIA, art.124(2), art.217(1).

18 THE CONSTITUTION OF INDIA, art. 121, art. 211.

${ }^{19}$ Constituent Assembly Debates, Vol. VIII, 258 (deciding on the independence of the judiciary was a key concern of the Constituent Assembly).

20 S.P. Gupta v. Union of India, A.I.R. 1982 S.C. 149 (independence of judiciary is the foundation of the Indian democratic polity rests. It also gave the executive the veto power over the collegium's choice).

21 Office of the United Nations High Commissioner for Human Rights, Basic Principles on the Independence of the Judiciary, http:// www2.ohchr.org/english/law/indjudiciary.htm (last visited Aug. 23, 2012). 
Independence of the Judiciary, 1997'22 emphasized the need for judicial independence. Also, a plethora of rulings pronounced by the Supreme Court have stressed the need for an independent judiciary. In State of Bihar v. Balmukund Shah,23 judicial independence was said to be a constituent element of the basic structure of the Constitution, the seeds of which were born in Keshavananda Bharati v. State of Kerala. ${ }^{24}$

Indian administrative law mandates that the possibility of misuse of discretionary power is no excuse for not granting it. But one wonders at the mechanism available to the victims of misuse of such power and its accessibility to the victims. It is well known that the poor don't 'access' the legal system and are drawn into it unwittingly in situations of conflict with the law. ${ }^{25}$ The inability of the poor to access the justice system can be attributed to illiteracy, cultural inhibitions, bureaucratic and political corruption.

The cruel hollowness of law is gradually revealed to the victims who undergo an endless process of re-victimisation. ${ }^{26}$ Therefore, it is crucial that judges are unusually insensitive to injustice. While placing a premium on judicial independence, the judiciary must capture and maintain the public confidence it seeks to protect.

The perturbing trend of hand-picking judges on the basis of undisclosed criteria reflects an increasing democratic deficit. Judicial independence is compromised when the executive has the

22 Lawasia \& the Asia Foundation, The Beijing Statement of Principles of the Independence of the Judiciary in the LAWASIA region, 1997, http://lawasia.asn.au/objectlibrary/147?filename=Beijing\%20Statement.pdf (last visited Aug. 24, 2012).

${ }^{23}$ A.I.R. 2000 S.C. 1296 at 294.

${ }^{24}$ A.I.R. 1973 S.C. 1461.

25 N.R. Madhava Menon, Legal Aid and Justice for the Poor, in LAW AND POVERTY: CRITICAL ESSAYS, 345 (Upendra Baxi ed., 1989) ("the poor come to use the legal system only when so compelled by being drawn into it as accused and defendants").

${ }^{26}$ Union Carbide Corporation v. Union of India, 1989 S.C.C. (2) 540 (Bhopal Gas Tragedy case); see also Narmada Bachao Andolan v. Union of India \& Ors., A.I.R. 2000 S.C. 3751. 
power to appoint or transfer judges, which is used to promote those who make 'correct' decisions. In the pre-1993 scenario, appointments were arbitrary and supersession was not uncommon. It is unfortunate that underlying the written constitution exists an unwritten constitution which embodies protocols of collaboration between the executive and the judiciary. The notion of the seniormost judge of the Supreme Court being elevated as Chief Justice is an aspect of this unwritten constitution. ${ }^{27}$ Though increasing transparency is strongly recommended there still subsists a valid fear that this could give room to the executive to step in.

\section{Judicial Accountability}

“Only virtuous people are capable of freedom"

Benjamin Franklin 28

Accountability functions on the framework of seeking integrity which is essential for the efficient functioning of any authority entrusted with responsibility. It primarily entails instilling a sense of transparency and subjecting the judicial regime to a strict public scrutiny so as to prevent any judicial delinquency.

It is crucial to understand the relevance of judicial accountability. Judicial independence cannot have an isolated existence because the faith of the citizenry can be reposed only in an accountable judiciary. Only an increased public perception of judicial accountability which is directly dependent on personal accountability can determine the degree of acceptable judicial independence. Thus, judicial accountability is a necessary means to reinforce independence and to ensure an effective judiciary. It is

${ }^{27}$ His Holiness Kesavananda Bharati Sripadagalvaru and Ors. v. State of Kerala and Anr., A.I.R. 1973 S.C. 1461 (three senior-most judges in the majority formation were superseded by Justice A.N. Ray in appointment as Chief Justice of India); see also Additional District Magistrate of Jabalpur v. Shiv Kant Shukla, 1976 S.C.C. (2) 521 (Justice H.R. Khanna was superseded by Justice M.H. Beg due to the infamous Habeas Corpus case).

28 Benjamin Franklin, To the Abbes Chalut and Arnoux, in THE Writings OF BENJAMIN FRANKLIN, Vol. X, 297 (Jared Sparks ed., 1840). 
therefore submitted that independence and accountability are two sides of the same coin and complement each other.

The need of an accountability mechanism also stems from the overassertiveness of the judiciary to the extent of declaring themselves immune from any form of enquiry into their actions. Such a reprehensible and autocratic practice makes it all the more onerous to ensure that an accountability mechanism to be operative, must establish that Judiciary is about the law and not above the law.

\section{Judicial Accountability v. Judicial Independence}

"The greatest strength of the judiciary is the faith people repose in it." 29

It is at this juncture that the long-standing debate between accountability impinging upon the independence of judiciary becomes significant. The propounding fore-fathers of the Constitution did not expressly provide for any mechanism to make the judiciary accountable. ${ }^{30}$ This was to prevent the violation of the fundamental edifice of judicial independence, a prerequisite for existence of a free and fair judiciary. ${ }^{31}$ The objective was to promote accountability through a mechanism of self-regulation without compromising the facet of independence. Greater accountability eradicates disastrous consequences of letting a dishonest adjudicator decide on the fate of the people who are the real stakeholders in the system of justice. ${ }^{32}$ Only in recent times have there been public outcries and debates for holding the judiciary

29 Secretary General, Supreme Court v. Subhash Chandra Agarwal, A.I.R. 2010 Delhi 159 | 73.

${ }^{30}$ Constituent Assembly Debates, Vol. VIII, 218.

31 While Article 235 was included to make the subordinate judiciary accountable to the higher judiciary, no similar provisions were enacted for the higher judiciary.

32 V. Venkatesan, Of Accountability to the People, FrontLine, Sept., 2009 at 33. 
accountable, with the civil society and the media assuming the role of alert watchdogs. 33

The Supreme Court on May 7, 1997 adopted a self-regulating mechanism in the form of a resolution. ${ }^{34}$ Later, the Chief Justice's Conference, 1999 endorsed the same, followed by the Bangalore Principles of Judicial Conduct, 2002. ${ }^{35}$ Unfortunately, due to the absence of any mechanism to verify the compliance of what was declared, there has never been any verification. India has also recently ratified ${ }^{36}$ the UN Convention against Corruption ${ }^{37}$, which provides for parties to 'take measure to strengthen integrity and prevent corruption in the judiciary'. ${ }^{38}$

It is rather ironical that despite being one of the few nations in the world where a Right to Information Act, 2005 (hereinafter 'RTI') legislation functions effectively, the judiciary seeks insulation from public view defending its independence and still refuses to make public information about the manner in which judges are appointed or transferred. It has gone to the extent of filing a Special Leave Petition directly in the SC against orders of the Chief Information Commissioner (hereinafter ' $\mathrm{CIC}$ ') asking the court to disclose information about the same. ${ }^{39}$ Further, contempt powers have also been used to ruthlessly silence outspoken criticism and

\section{See Chaudhury, supra note 4.}

${ }^{34}$ Restatement of Values of Judicial Life, http:// www.judicialreforms.org/ files/restatement_of_values_jud_life.pdf (last visited Aug. 24, 2012).

35 Judicial Group on strengthening Judicial Integrity, The Bangalore Principles of Judicial Conduct 2002, http:// www.ajs.org/ ethics/pdfs/ Bangalore_principles.pdf (last visited Aug. 24, 2012).

${ }^{36}$ India ratifies UN Convention against Corruption, THE HINDU, May 12, 2011, http://www.thehindu.com/news/national/article2012804.ece.

37 United Nations Convention against Corruption, http:// www.unodc.org /unodc/en/treaties/CAC/index.html (last visited Aug. 24, 2012).

38 UN General Assembly, United Nations Convention Against Corruption, 31 October 2003, A/58/422, art. 11.

${ }^{39}$ CPIO, Supreme Court of India v. Subhash Chandra Agarwal, 162 (2009) D.L.T. 135. 
public exposure of corruption in the judiciary. The shying away from making oneself accountable is sheer naivety as integrity is a means of achieving judicial independence.

\section{Muzzling the Solution?}

Unless the level of corruption in the judiciary is exposed and brought out in the public domain, the institutions of governance cannot be activated to take effective measures to eliminate this evil. However, the draconian power of contempt is often used by the judiciary to target public or media scrutiny of judicial misconduct. ${ }^{40}$ There seems to be an irony in the fact that the judges seek to shield themselves through such coercive measures.

Confidence in judiciary is maintained by the public perception of the actions of the judiciary and the conduct of its judges over a long period of time. People should be allowed to make an honest fair criticism about the working of the judiciary. To punish and stifle public criticism in an attempt to muzzle dissent seems futile and any such measure would cause far greater damage and lead to a backlash, tarnishing the image of the judiciary. It would make people suspicious that things are more seriously amiss than they had suspected, engendering greater resentment, negating the objective of the Law of Contempt. 41 Thus, the power vested through the Contempt of Courts Act, 1971 which imposes a fetter on the freedom of speech, should be invoked only as a regulatory measure with utmost caution.

Shanti Bhushan, Senior Advocate of the Supreme Court has raised a historic challenge by questioning the integrity of the highest

40 Prashant Bhushan, Judicial Accountability or Illusion: The National Judicial Council Bill, ECONOMIC \& POLITICAL WeEKLy, Nov. 25, 2006, http://www.judicialreforms.org/files/judicial_acc_or_illusion_pb.pdf (the "sword of contempt" has removed any form of public criticism).

41 Journalists Sentenced for Uncovering Corruption, WORLD PRESS, Sept. 25, 2007, http://www.worldpress.org/Asia/2941.cfm; see We have taken truth to be our defence: Vitusha Oberoi, THE HINDU, Sept. 21, 2007, http:/ / www.hindu.com/thehindu/holnus/001200709211658.htm; see also Re Arundhati Roy (2002) 3 S.C.C. 343. 
judiciary and making charges of corruption against eight of 16 past Chief Justices of India, thereby posing a serious peril before this Republic's crimson future. In an astonishing event, the rarest of the rare kind, he has also defiantly challenged the judiciary to take action against him for contempt.

Parliament must act on this matter of paramount importance and move a motion appointing the highest quasi-judicial body to inquire into the matter. It should be a historic, epic tribunal to try its own judges and it requires an appropriate high-level investigation, with consequential follow-up action that is punitive and reformatory. This is no time to hesitate or involve in an exchange of rhetoric, since remaining deaf or dumb in this situation will be a matter of shock and shame.

If Mr. Bhushan fails in his bid, let him face the consequences of his phenomenal folly. There should be no contempt proceedings to hide delinquent conduct, no secrecy but only transparency, in an epic battle more important than the making of the Constitution. It should be a national hearing by a superlative tribunal which would be a unique, brave judicial odyssey. For, never has such a challenge been raised to a nation's supreme body.

\section{People's Right to Know and the Need for Maintenance of Secrecy in Public Interest}

It is significant to note the importance accorded to 'right to know' by the apex court as the irony of the situation hinges upon the same with the impervious judiciary seeking an immunity from the dissemination of information of its own players.

"In a government of responsibility like ours, where all the agents of the public must be responsible for their conduct, there can but few secrets. The people of this country have a right to know every public act, everything, that is done in a public way, by their public functionaries. They are entitled to know the particulars of every public transaction in all its bearing. The right to know, which is derived from the concept of freedom of speech, though not absolute, is a factor which should make one wary, when secrecy is claimed for transactions which can, at any rate, have no repercussion on public security. To cover with veil secrecy the 
common routine business, is not in the interest of the public. Such secrecy can seldom be legitimately desired. It is generally desired for the purpose of parties and politics or personal self-interest or bureaucratic routine. The responsibility of officials to explain and to justify their acts is the chief safeguard against oppression and corruption." 42

The Supreme Court has also declared it mandatory for all electoral candidates to make public the details of assets owned by them, their spouses and dependants. ${ }^{43}$ Judges are 'public servants' under the Indian Penal Code, 1860 and the Prevention of Corruption Act, 1985 and must stand on the same footing as other public servants.

\section{Judicial Privacy v. Judicial Accountability}

Amidst the controversies surrounding the issue of disclosure of assets, a bold judgment was delivered by the Delhi High Court in the CPIO, SC of India v. Subhash Chandra Agarwal44 (hereinafter 'SC Judges Assets case'), on September 2, 2009, ruling that the Chief Justice of India could not claim immunity from applicability of the RTI Act, 2005.

This decision calls for transparency measure in governance, endorsing the right of the citizens to know the acts of public authorities. Scathed with criticisms and a fair share of accolades, the ruling is surely a benchmark in the Indian jurisprudence.

The Appellant had sought to know whether the judges were complying with the Code of Conduct adopted at the full meeting of the Supreme Court in May, 1997. The Supreme Court had been making a distinction between the information held by the Chief Justice's office and by the Supreme Court which was outrightly rejected by the CIC. The CIC ruled that Supreme Court is an institution created by the Constitution and is thus a 'Public Authority'.

${ }^{42}$ State of U.P. v. Raj Narain, A.I.R. 1975 S.C. 865 \ 74.

${ }^{43}$ Union of India v. Association for Democratic Reforms, A.I.R. 2002 S.C. 2112.

44162 (2009) D.L.T. 135. 
The Supreme Court petitioned the Delhi High Court against this order of the CIC, claiming exemption from disclosure of assets under the RTI Act, 2005 as the judges disclosed this information to the CJI under a "fiduciary relationship" and that it was "personal information having no relationship to public interest and would cause an unwarranted invasion of privacy" of judges. It further claimed that the CJI was not a 'public authority' under the RTI Act, 2005. The Supreme Court still maintains this stance despite the declaration of assets on the court's website. His Lordship, Justice Ravindra Bhat rejected these claims and held that the CJI had to disclose the information about assets. Since the code of conduct was adopted by the judges themselves, there could not be any claim of fiduciary relationship.

In its appeal against the Delhi High Court order, before its Division Bench, the Supreme Court contended that there was no law providing for declaration of assets to the Chief Justice of India. Information could be sought only if it was held by or was under the control of any public authority under the provision of any statute or any law. It claimed that there was a plethora of information which was available with the judiciary but could not be made public.

The court observed that "well-defined and publicly-known standards and procedures complement, rather than diminish, the notion of judicial independence." 45 Affirming the earlier observations it held that the phrases 'held by' or 'under the control of' under Sec. 2(j) of the RTI Act, 2005 also includes information received or used or consciously retained, by any public authority in its official capacity. The declarations to the Chief Justice of India are made in discharge of the constitutional obligation to maintain higher standards and probity of judicial life and thus, are in larger public interest. The mechanism for declaration of assets should be fair, objective and transparent with a clear set of guidelines. It is opined that disclosure will have little or no impact without open public access or oversight.

45 Secretary General, Supreme Court v. Subhash Chandra Agarwal, A.I.R. 2010 Del. 159. 
It is pertinent to note that the court accorded right to information a status of a constitutional right by not exempting the office of the Chief Justice of India from the transparency framework. Right to information facilitates a vibrant democracy by assisting citizens to gather information required to participate in the democratic process and thus, to have the governors accountable to the governed. The decision comes as a ray of hope in the fight against corruption which has now become a living reality.

\section{The Judicial Standards and Accountability Bill 2010}

The deepening crisis and public debate catalyzed the need for judicial accountability through The Judicial Standards and Accountability Bill, 2010, emphasizing the need of preserving the sacrosanct judiciary in the epoch of weakening credibility. This Bill is the legislature's third attempt in making the judiciary transparent. It lays down judicial standards of conduct and provides for the accountability of judges by establishing mechanisms for investigating even individual complaints. The Bill seeks to establish the National Oversight Committee, ${ }^{46}$ Judicial Scrutiny Panel ${ }^{47}$ and an Investigation Committee. Also, it makes annual declaration of assets of the judges mandatory. To protect the judge from defamation, the Bill exempts documents and records of the proceedings pertaining to the complaint from the purview of the RTI Act, 2005 while making the report public. It prohibits the participants from revealing any information regarding the investigation. Having stringent penal provisions in place to check any breach of confidentiality of complaints, it prescribes punishment for frivolous complaints with a maximum of 5 years imprisonment and Rs. 5,00,000 as fine. This mechanism seems rather undesirable as the complaint remains confidential.

\footnotetext{
46 Chaired by a retired Chief Justice of India and comprising of a judge of the S.C. nominated by the Chief Justice of India, Chief Justice of the High Court, Attorney General and an eminent person appointed by the President.

47 Comprising of a former Chief Justice and two sitting judges of the concerned court.
} 
The National Oversight Committee has the power to issue advisories or warnings to judges and can also recommend the judge's removal to the President. The imposition of minor measures by an oversight bodies constituted entirely from amongst the judiciary had been declared valid. ${ }^{48}$ But it is better to have a broad based screening committee conducting the preliminary investigations which can give adequate representation to members from the executive, legislature, judiciary as well as the Bar. This being a broader based committee would be impartial, transparent as well as credible.

Also, the provision of appeal to the Supreme Court, a creation of a Supreme Court judgment ${ }^{49}$ allowing a judge to seek 'judicial review' against a Presidential order for his removal has not been negated by the Judicial Standard Accountability Bill, 2010. It put forth that this is against the constitutional provision of the Presidential Order not being open to challenge.

Despite the judgment by the Delhi High Court that created ripples in the judicial circles, the introduction of the Bill seems to be a halfbaked effort as the legislation falters on various counts. The process of impeachment remains the same, which is painfully long and almost next to impossible to execute. It seems to be motivated only to restore public confidence through a confidence trick and clearly lacks the will to bring about a change.

While this rather radical step on the part of legislature is indeed a welcome change in this era of growing concern towards good governance, the Bill might not lead to a balanced law, running the risk of reducing it to a mere paper tiger. Concerns about the same seem to have already surfaced as the road to reform the judiciary seems to be a bumpy ride, requiring apt redressal.

\section{Time to Off-load}

The appointments to the Judiciary have not been able to keep pace with the vacancies, due to haggling at every step over political,

${ }^{48}$ C. Ravishandran Iyer v. Justice A.M. Bhattacharya, 1995 (5) S.C.C. 457.

49 Sarojini Ramaswami v. Union of India, A.I.R. 1992 S.C. 2219. 
caste or communal considerations. ${ }^{50}$ The Collegium of judges which is consulted in the matter of appointment of judges suffers from a distressing handicap in its process of selection of judges and is pilloried for making wrong choices or even overlooking the competent contenders. The list of meritorious judges who failed to make it to the apex court is perhaps rather long.

The apex court, in the absence of a Secretariat is overburdened with administrative work. The Collegium lacks the necessary resources to investigate into the competence, character, and integrity of candidates. This makes the Collegium to resort to informal consultations with other judges or members of the Bar. This is a poor substitute for intensive data collection about the nominees' qualifications, standing, merit, integrity, and potential. Thus, the Collegium inevitably picks up from the senior-most judges, overlooking several talented junior judges.

The Collegium's deliberations being secret and the opaqueness of the system further insinuate the flack it receives for its misadventures. Sitting judges do find it awkward and embarrassing to hold their brother judges, guilty of misdemeanours.

In certain countries like the UK, South Africa and Canada, National Judicial Appointment Commissions have been instituted to appoint judges. They have an advantage as they being independent and broad-based, represent the views of the judiciary and also those of the executive and other sections of society. The size of the Indian judiciary makes it pertinent to have two separate judicial commissions, for the Supreme Court and the High Courts respectively.

50 Moily: Adopt Campaign Mode for Speedy Justice, THE HINDU, May 12, 2011, http:/ / www.thehindu.com/todays-paper/tp-national/ article2011015.ece?css=print (there are currently 288 vacancies in High Courts across India). 


\section{An Evaluation of the Mechanisms Available to Check Corruption in Judiciary}

Mahatma Gandhi had aptly remarked: "Law is nothing but the convenience of the powerful." 51

A mechanism for accountability being fundamental to a democratic framework is irreplaceable in ensuring that Part III, IV and IVA of the Constitution do not remain a mere illusion. The ordinary process of removal of a Judge by way of impeachment, being rather cumbersome, has resulted in total immunity to corrupt judges against their prosecution, leading to an increase in corruption by leaps and bounds. To have the already overburdened sitting judges to investigate is an inefficient use of resources. It also tends to promote the view that the judiciary is accountable to no one but itself.52 A neutral and objective accountability is required as opposed to the adoption of an in-house procedure to provide a mere lip service.

An alternative can be an Ombudsman, who could inquire into complaints against the judges, followed by a consultation with the Chief Justice and take the requisite steps. ${ }^{53}$ Ombudsman can also review and monitor declarations of assets made by public officials. United Kingdom, ${ }^{54}$ Sweden $^{55}$ and Israel $^{56}$ are a few countries

\footnotetext{
51Sasheej Hegde, Lawyers and the Legal System in India: A Critique, READINGS IN THE SOCIOlOGy OF THE PROFESSIONS 354 (Sheo Kumar Lal \& Kirti Khanna ed., 1988).

52 Bhushan, supra note 40.

53 Crisis: we need ombudsman over SC collegium: Nariman, EXPRESS INDIA, Sept. 19, 2009, http://www.expressindia.com/latest-news/Crisiswe\%E2\%80\%93need-ombudsman-over-SCcollegium/Nariman/519019/.

54 Judicial Appointments and Conduct Ombudsman, (Feb. 17, 2012) http://www.judicialombudsman.gov.uk/.
}

55 The Parliamentary Ombudsmen, http://www.jo.se/Page.aspx? Language=en (last visited Aug. 24, 2012).

56 Ombudsman of the Israeli Judiciary, Ministry of Justice, http:// www.justice.gov.il/ MOJEng/Ombudsman/ (last visited Aug. 24, 2012). 
having the ombudsman system in place. An identical officer present in South Africa is the Public Protector. ${ }^{57}$

\section{Recommendations}

Independence of the judiciary means independence from the Executive and the Legislature, but not independence from accountability. Accountability is an integral part of democratic polity. ${ }^{58}$ The higher judiciary sets the standard for judicial conduct and competency and thus, only those with absolutely unimpeachable integrity and quality should be appointed to these courts, so that they perform their duty with utmost dedication and skill.

Voluntary public disclosure of assets by judges does not seem to be the solution. A constitutional code of conduct and behaviour is needed for the judges. When a finger is pointed at them, a commission of critical incisiveness must be prompt to investigate into charges and if found guilty, they should be removed without impeachment. Impeachment for judicial misconduct seems to be an extravagant affair involving too much of the administrative machinery.

Where there is a high demand for corrupt services it is highly unrealistic to expect incentives such as higher salary alone to offset delinquency. A credible threat of sanctions through institutional control mechanisms is much needed in such a scenario. Prior to becoming judges, they usually amass huge assets while practicing as lawyers and thus, the dignity and power attached to the post of the judge is its only incentive. Therefore, heavy monetary sanctions would rarely serve the purpose which a public humiliation in the form of inquiry or impeachment could do.

57 Public Prosecutor of South Africa, http://www.publicprotector.org/ (last visited Aug. 24, 2012).

58 Smt. Indira Nehru Gandhi v. Shri Raj Narain and Anr., A.I.R. 1975 S.C. 2299. 
With the appeal in the Second Judges Assets Case now lying with the Apex Court to be decided by a constitutional bench, ${ }^{59}$ the greater question looming at large is can the court adjudicate upon a matter in which it is an interested party? In the light of the allegations advanced against several members of the Bench, it seems imperative to us that clear guidelines concerning the constitution of the Bench to hear the matter should be framed.

Also, it is pertinent to note that the Constitution should be amended to alter the convention of seniority for elevation as Chief Justice of India. The process to ensure accountability seeks to enhance the integrity and capacity of the judiciary as a whole. An independent full time National Judicial Commission is inevitable for a transparent method for selecting and appointing judges as well as for investigating complaints against them. It is recommended that this Commission should adopt a procedure of submitting a list of candidates from which the judiciary can make its choice. The nominations should be based on the fairness and impartiality of the judge, while taking into account his intelligence and diligence. 60 Personal characteristics and potential impediments should be discussed with a scrutiny of his past record.

Similar procedure should be adopted to investigate all allegations against judges and take action. The committee in this case should be given the power to summon witnesses, require production of documents and take evidence. This would ensure accountability keeping the independence of the judiciary intact and uncompromised. The proper functioning of this Commission will go a long way in restoring the lustre of the judiciary and transform the Supreme Court of India into Supreme Court for Indians.

592010 (12) SCALE 496.

${ }^{60}$ Law Commission of India, Reforms in the Judiciary - Some Suggestions, 230 th Law Commission Report, Aug. 2009, http:// lawcommissionofindia.nic.in/reports/report230.pdf. 